\title{
Sailing towards the Peloponnese: The Strophades Islands
}

The next morning [...] we approached at our right a beautiful and fertile island called Strophaies [...] which is inhabited only by Orthodox monks in a monastery dedicated to the Virgin. ${ }^{1}$

Having left Corfu, and while sailing through the Ionian Sea towards the Peloponnese, most of the pilgrims' galleys would pass near the two small islets of the Strophades. Their location in the open sea on the main route connecting Venice to the Holy Land, as well as the wells of potable water that could be found at the larger one of them, made them a popular stopping point for the ships travelling through the Ionian (Fig. 37). Built on the larger island of Stamfani, the monastery of the Virgin provided an additional reason for ships carrying religious travellers to dock at its port; the Virgin of Strophades was highly venerated by the seafarers, who integrated it into their holy sailing topography, as expressed in the Santa Parola litany.2

The site is of a peculiar nature. It is not exactly a port, nor a town, nor even a settlement, and not exactly a monastery. It is a strong fortress housing a monastery, built on the shore of a small islet, on what can be described as a little natural docking point (Fig. 38). The fortified monastery was manned - at least during the time frame of this study - by a cenobitic community of Greek Orthodox monks. Thus, conceptually, visually and geographically, it is a liminal space, on the borders between land and sea and between the earthly and heavenly dimension.

1 Nicolas Loupvent (1531), see n. 16 below.
2 About the Santa Parola litany, see p. 12, n. 11 herein. 


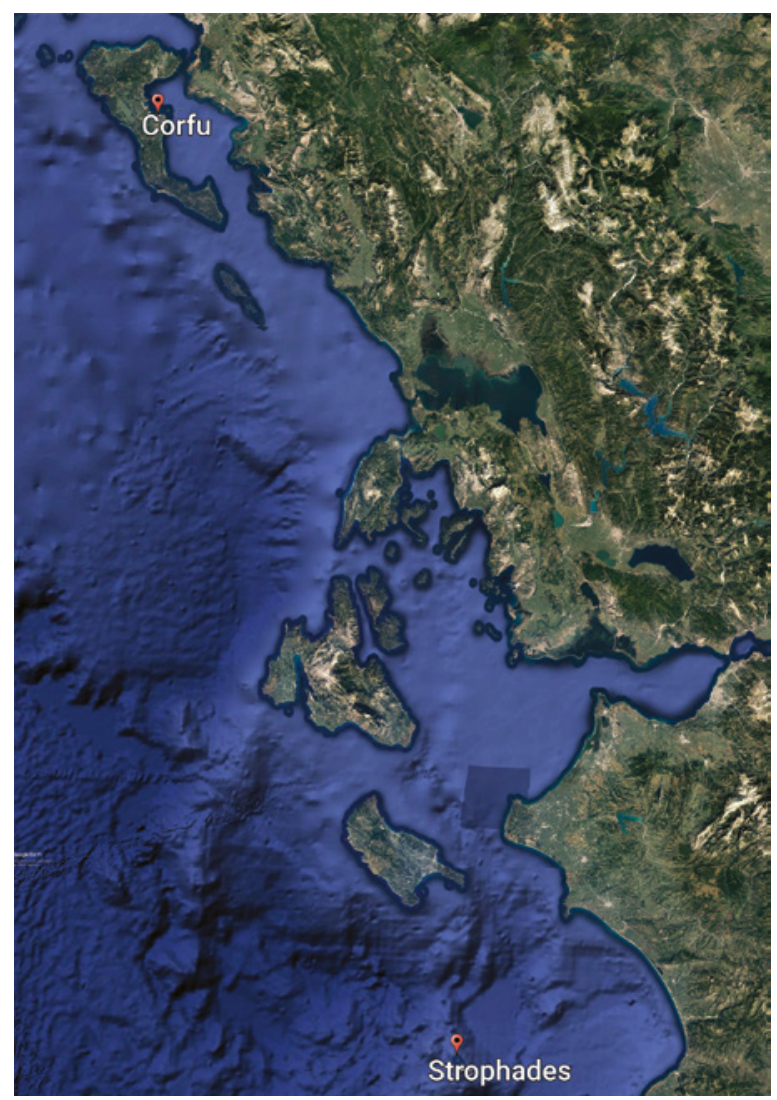

FIGURE 37 Map indicating the location of the Strophades islands

After 828 and the translation of St Mark's body to Venice, the area was invested with a miracle, thus becoming famous among Christian mariners and sea travellers: according to the legend, the Strophades were initially one island, which by divine intervention was divided in two in order to make way for the ship carrying the apostle's relics from Alexandria to Venice (Fig. 39). ${ }^{3}$ The Florentine nobleman Lionardo Frescobaldi, who travelled to the Holy Land in 1384, was the first pilgrim to provide an attestation of the said wonder. ${ }^{4}$

3 Maltezou 1999, 9-10; Merkouri 2020, 24.

4 ' [...] una isoletta divisa in due parti, la quale si dice si divise per sé medesima quando i Viniziani recarono dalla città d'Alessandria a Vinegia il corpo di san Marco Evangelista, facendo luogo alla nave'. Lanza 1990a, 174. 


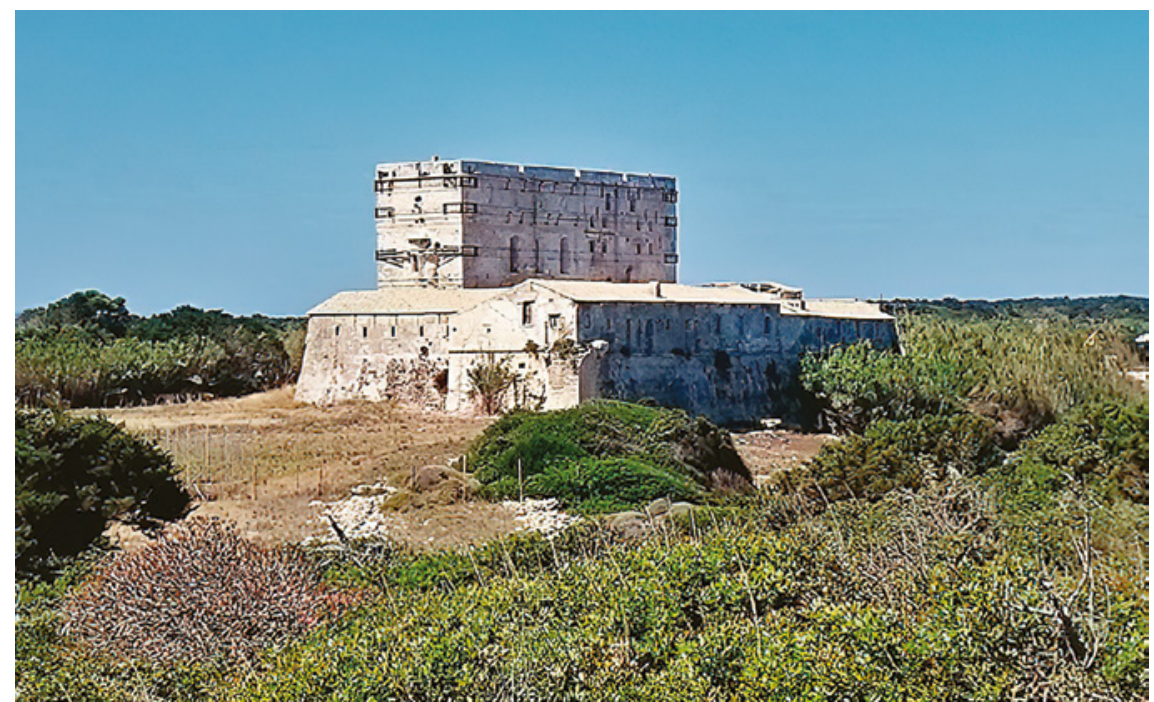

FIGURE 38 The monastery of the Virgin of Strophades

Following Frescobaldi, several other pilgrims, who either sailed near or actually stopped at the Strophades, mention the miraculous division. In 1425 an anonymous English traveller writes:

A wounde miracle there was wroght,

When S. Marke from Alexander was broght:

And was translatet in to Venece,

The Galiez comen be that waiez.

And when the Galiez come zeder thoo,

The Ile cleved even in too:

And the Galiez token even the same waie,

So thennez the see in to this daie. ${ }^{5}$

This miracle constituted a link that associated the two islands to Venice via its most revered patron saint. The Strophades thus became a part of the translatio of St Mark's relics, an essential part of Venice's national myth. ${ }^{6}$ This

5 Purchas 1905,547 .

6 About the miracle and the connection of the monastery to Venice, see Kolyvà 2015. 


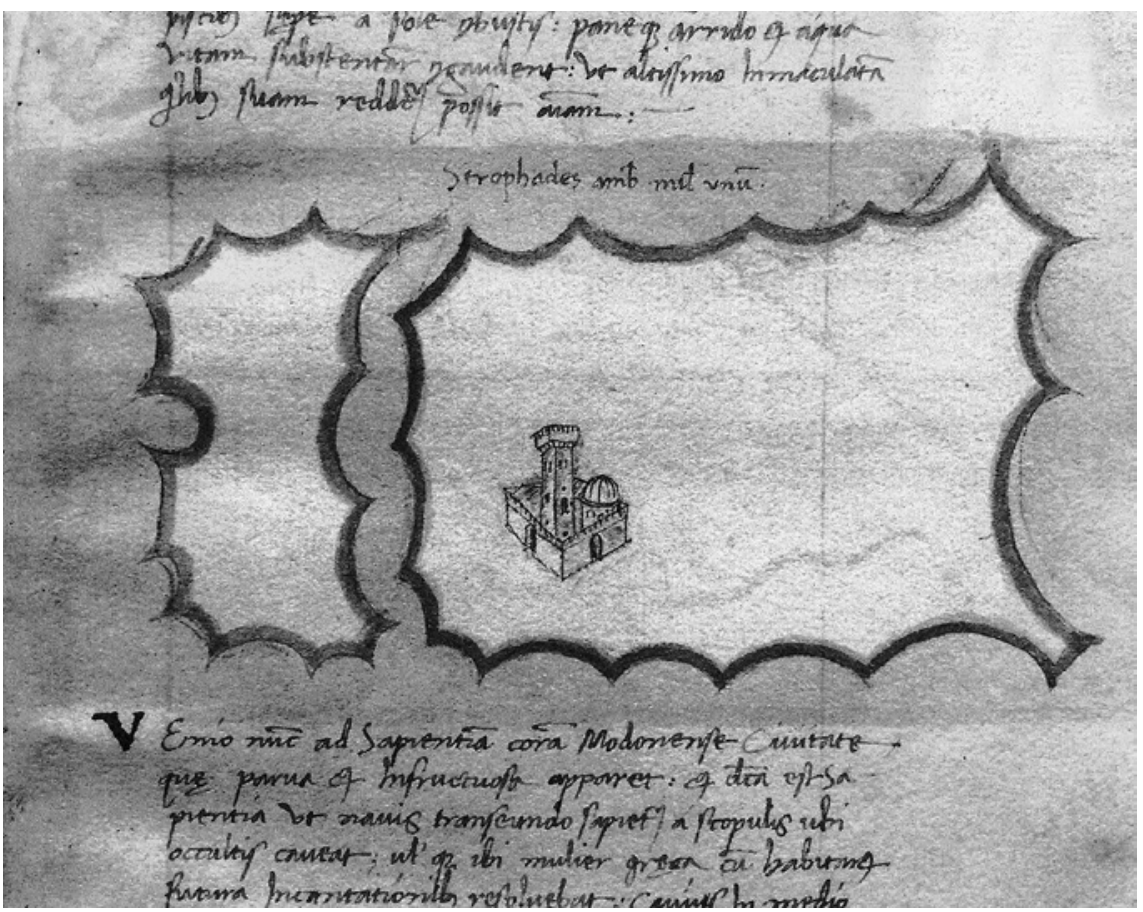

FIGURE 39 The Strophades islands and the monastery of the Virgin, $c .1420$, manuscript illumination

correlation was invoked at least once by the monastery's monks, when, in 1532, they requested from Venice building materials, as well as defensive weapons, since the times were turbulent and the monastery's tower had been damaged by an earthquake. ${ }^{7}$ In his epistle the abbot, Daniel, underlines the monastery's relation to Venice, proven by the mosaic 'to the right of the entrance of San Marco.' ${ }^{8}$ His letter continues with a detailed description of the miracle as a confirmation of the monastery's link to Venice, also stating that ever since the

7 The letter was sent on 29 April 1532 by the monastery's abbot, Daniel. See Sanuto 1903, col. 266. The letter is published in Kolyvà 2015, 196.

8 '[...] è questo monasterio et edificio special et proprio de San Marco et alzate gli ochi quando intrate per le porte di San Marco, a dextris, vederete come è depento et scritto de musaico inaurat'. Sanuto 1903, col. 266. 


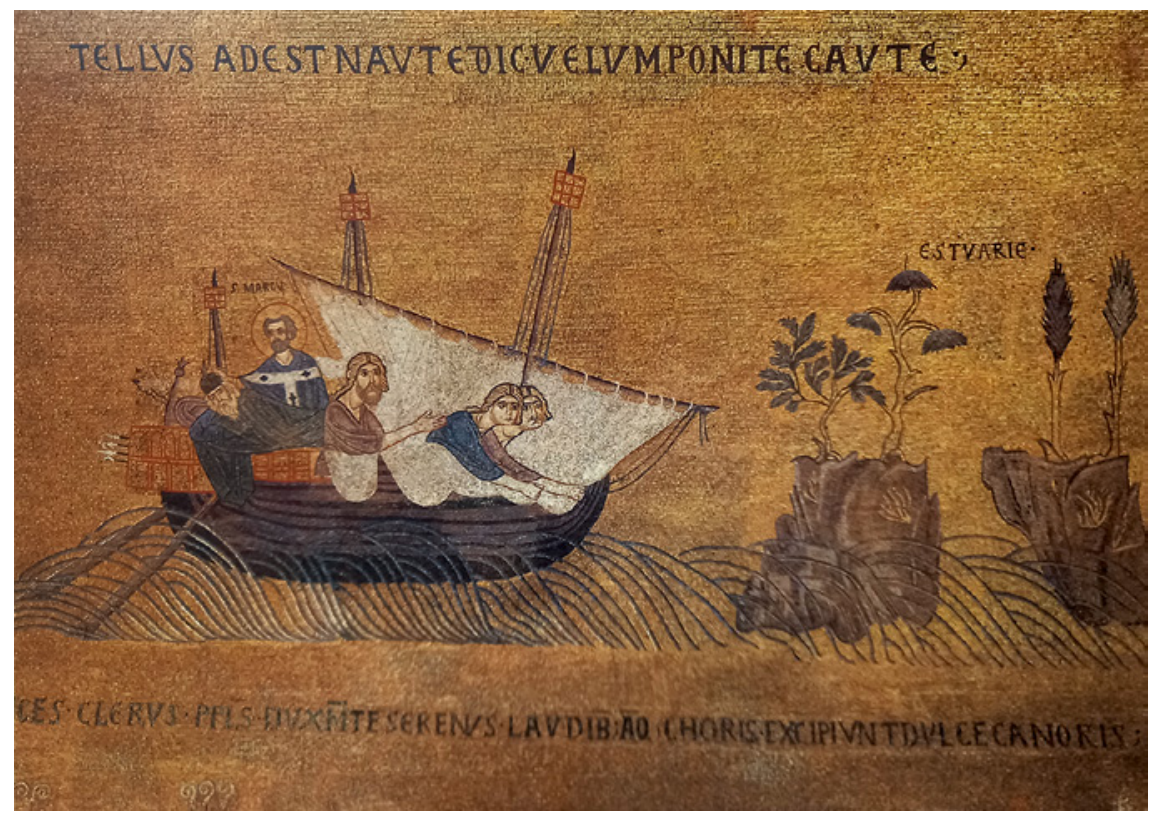

FIGURE 40 The mosaic depicting the miracle performed at the Strophades

miracle, that is, the 9th century, members of the Venetian Loredan family have been the procuratori of the Strophades. ${ }^{9}$

Information about the miracle, but, most importantly, about the mosaic depicting it, is conveyed by the Flemish nobleman Joos van Ghistele (14811485), who after describing the salvation of the ship carrying the apostle's relics, mentions that one can still admire its depiction in San Marco in Venice (Fig. 40). ${ }^{10}$ The mosaic mentioned by Abbot Daniel and the Flemish pilgrim is

9 According to the relation of the miracle in the abbot's letter, as the ship carrying the saintly relic was travelling near the island, St Mark miraculously arose and took the rudder to avoid crashing onto the rocky shore. He sailed straight ahead, while the island was splitting in two to make way for the ship. When the sun rose, the passengers saw the miracle and stayed on the new island for five days. After arriving safely in Venice, they narrated their miraculous salvation and '[...] la Signoria mandò ad edificar el monasterio.' Sanuto 1903, col. 266; Kolyvà 2015, esp. 181-184, 196.

10 The full text reads: 'Ter welcker plecken eens een groot mirakel ghebuerde, als den lichame van Sente Maerc evangeliste, patroon van Venegien, uut Alexandrien ghebracht was, te wetene dat bij fortunen van grooten winde tscip daer thelich lichaem van Sente Maerc in was, groot zijnde acht hondert booten of vaten, bij fortsen de zee rumen moeste, ende de scippers gheen meester zijnde vanden scepe, quamen dweers up tvoornoemde heylandekin, ende zonder eeneghe scade den scepe te gheschiene, seylden duer tvoorseyde cleen canael of aermkin vander zee, da[t] zonder mirakel niet en hadde moghen 
no longer extant, but its presence is attested to by art historians. Otto Demus published pictures of the representation, the oldest full cycle of the translatio of St Mark's relic, located in the chapel of St Clement, and dated it at the first quarter of the 12th century.11

As the 15th century was coming to its close and while the Ottoman threat was expanding in the area, most of the narratives focussed on the monastery's fortification and its 'warrior' monks who pushed away Ottoman pirates. ${ }^{12}$ This could be the source of the creation of yet another myth in relation to the Strophades, according to which only Christian ships could pass unharmed between the two islands. ${ }^{13}$

The two small islands, the monastery of the Virgin and St Mark's miracle are mentioned in many pilgrims' narratives. Located in open sea, in a spot distant from other ports or docking points and being on the ancient sea route leading from the West to the East and vice versa, the larger of the two islands provided a much needed safe harbour, as well as fresh drinking water, so important for sea travellers. The monastery of the Virgin, on the other hand, provided the notion of divine protection and the promise of a safe and blessed journey. Thus, it comes as no surprise to see it mentioned in a significant number of travelogues. Added to the above, which would constitute reason enough for the monastery to be present in pilgrims' narratives, the monks living there became yet another. They were devout Orthodox, leading a very strict life of fasting, while at the same time they appear to have been heavily armed, protecting their small piece of land from Ottoman and pirate raids. These 'caloyeri', their way of life and especially their status as armed defenders of the monastery and, by extension, the Christian faith seem to have really intrigued the pilgrims. ${ }^{14}$ Almost none of them, when mentioning the monastery, omits to refer to its 'warrior' monks.

gheschien. Men siet als noch de pointratuere te Venegien inde keercke van Sente Marc vanden zelven mirakel.' Gaspar 1998, 391.

11 Demus 1988, 33-38; Kolyvà 2015, 191-193.

12 Paul Walther Guglingen (1481-1483): 'Et singuli habent arma omnia bellica tam sacerdotes quam laici in communitate et omnia alia requisita ad bellandum, et usque hodie semper defenderunt se a Thurcis.' Sollweck 1892, 8o.

13 In 1495 Count Alexander von Pfalz-Zweibrücken referred to the legend: 'Man sagt, alle Schiffe, die fahren aus Konstantinopel, Alexandria und anderswo, die Christenleuten zugehören, müssen durch die zwei Insel fahren. Wiewohl es zwischen den zwei Inseln fast eng und steinig ist, dannoch ist nie gehört worden, dass einig der Christen Schiff da verdorben sei, aber türkische und ungläubiger Leute Schiffe mögen durch die Inseln nicht fahren, sondern müssen umfahren bei 5o oder 6o Meilen Wegs.' Karbach 1997, 56 .

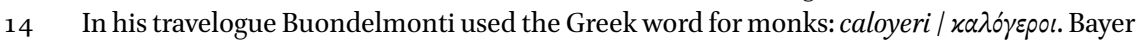
2007, 13. Almost all of the pilgrims referring to the monks used similar terms: caloyers, kalorier, kaloeri, etc. 
The first impression of the strongly fortified monastery seems to be common for most of the pilgrims. Cristoforo Buondelmonti, who travelled in 1420, describes it as a tower with a church. ${ }^{15}$ One of the more vivid descriptions, combining almost all of the facts mentioned in the travelogues, is provided by the French Benedictine monk Nicolas Loupvent, who dedicates several lines to describing the small island, inhabited only by Orthodox monks, whom the neighbouring lords admire for their deep devotion and who trust them to defend their monastery against the Ottomans and the infidels. ${ }^{16}$

Located on the small port, the tower housing the monastery of Strophades and its surroundings has not changed significantly over the centuries (Fig. 41). Thus, a quite accurate re-enactment of the pilgrims' site-related experience can be attempted. As the galleys approached the island, their passengers could see from aboard the strong and tall tower that housed the monastery. The surrounding rocky landscape with low vegetation would be particularly imposing, especially if the ship was approaching at night-time. Since most of the large ships did not dock at the small port, it is highly questionable if the pious passengers actually disembarked at the island. In the case that they did, the pilgrims would enter the tower and visit the monastery's katholikon, located on the building's first floor. At this point, it should be stressed that up until the renovation and enlargement of the monastery in 16og, the katholikon was a small church built in the 13th century, which had undergone only minor renovations, presumably adorned with murals and decorated and structured in a way completely different to what a Westerner would be accustomed to. The miraculous icon of the Virgin, located on the iconostasis with a perpetual lamp burning in front of it, would have been surrounded by votive offerings. All of the above, combined with the narrations of the seafarers about the miracles connected to the island, the monastery and its icon, as well as the monks

\footnotetext{
15 '[...] turris cum ecclesia est'. Bayer 2007, 13.

16 The full text reads: 'Le landemain matin, questoit vendredy xiıII de jullet, environ $\mathrm{x}$ heures, vimmes a approchier a la main destre une belle jolye et fertile isle nomée Strophaies quest distant de lisle de Jante xxx mil, le tout sy fertile que rien plus, laquelle est seulement habitée dune religion et monaster de lorde de sainct Basille en lhonneur de Notre Dame, tenant lusaige et lanque grec, et sont tousjours en nombre sil est possible cinquante religieux. Et est le lieu sy trèsfort quilest dict religion inexpugnable, et font foy les seigneurs voysins que jamais aincor le turc ne la peu avoir tellement ont iceulx religieux moinnes résisté, et est ladite isle et pays totalement a iceulx religieulx sans reprinse ny recongnoissance daulcuns a cause que les véniciens leurs ont quictté pour la grande et fervant dévotion quest en eulx et ausey pour la diligente virilité quils prainnent de résister audictz turques et infidèles.' Bonnin 1976, 52 .
} 


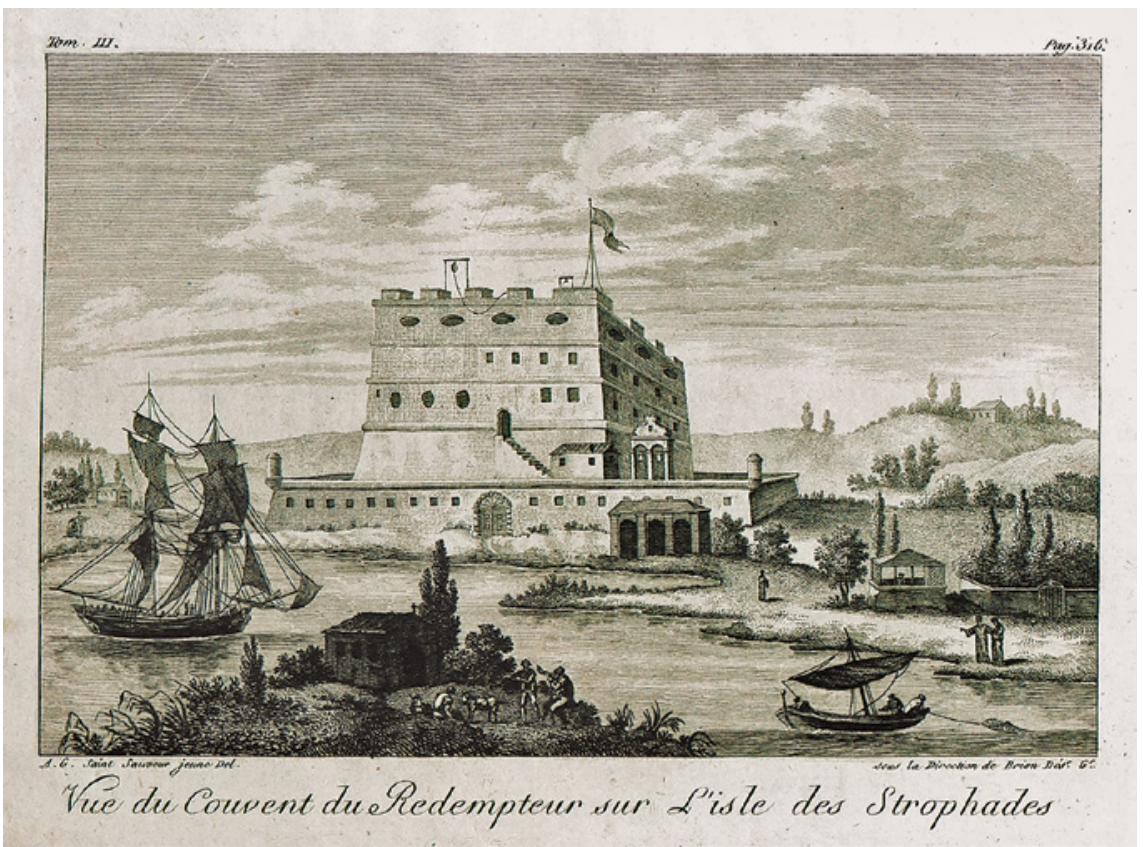

FIGURE 41 The monastery of the Virgin of Strophades, $c$. 180o, engraving

living in it, certainly made the pilgrims' experience of visiting the Strophades undoubtedly different, strange and interesting.

As a result, a significant number of pilgrims referred to the 'beautiful and strong monastery' on the island, but the monks living in it also attracted their attention. ${ }^{17}$ Reading the travelogues, it becomes clear that the monks had acquired a certain fame among the travellers, obviously because of the incompatible nature of their two main characteristics: devout cenobitic monks, yet heavily armed and engaging in battles with pirates or Ottoman intruders. Combining information provided by pilgrims' testimonies, one can recompose a quite accurate picture of the monastery and the life of the monks residing in it. 18

17 Roberto da Sanseverino (1458-1459): ‘[...] bello et forte monastero [...]'. Cavaglià and Rossebastiano 1999, 115 .

18 In 1420 Cristoforo Buondelmonti wrote: '[...] in quibus turris cum ecclesia est, et caloyeri horis canonicis in ea conueniunt, ubi gumicius uel prior uita sanctorum patrum coram omnibus legendo declarat. igitur, quid sit uita istorum, indica, pater, quia certissime asperrima reputatur. [...] ibi carnes neglecte sunt et cum piscibus sepe a sole combustis 
The cenobites, Greek Orthodox as clearly stated by all of the pilgrims mentioning them, led a very strict life, with a diet restricted to fish, bread and water, and also protected their monastery, as seen through the eyes of religious travellers: the Christian faith against the infidel Ottomans. ${ }^{19}$ Women were prohibited from stepping on the island, while female animals were kept at the neighbouring small islet of Harpy:

There ben holy Monkez duellande, In a Mynster of our Lady,

And there thei lif full honestly:

And nother woman, foule, ne best,

And thei wull agazn there lest,

Nis non femenyn gender,

Thei maie not there endure. ${ }^{20}$

Oddly enough, and while the pilgrims seem to be very interested in the fortified monastery and its monks, none of them directly mentions the monastery's most revered icon, the miraculous icon of the Virgin Thalassomachousa. It is well known from other sources of the period that this icon was kept and venerated in the monastery of Strophades. Its presence might actually have been the reason for the monastery's dedication to the Virgin. ${ }^{21}$ Nevertheless, in none of the travelogues mentioning the Strophades is there a direct reference to the icon, even though the small fortified monastery of the island has an uninterrupted presence in pilgrims' travelogues throughout the 14th to the 16th centuries.

paneque arido et aqua uitam sustentare congaudent, ut altissimo immaculatam quilibet possit reddere uitam.' Bayer 2007, 13 .

19 Pilgrims referring to the Strophades monks, besides using variations of the Greek word caloyeri, also added that they are 'de lorde de sainct Basille', meaning of the Orthodox rite. Roberto da Sanseverino (1458): ‘[...] di observantia di Sancto Basilio [...]'; Felix Fabri in 1480: '[...] monachi graeci regulae S. Basilii [...]'; Paul Walther Guglingen in 1482: '[...] ordinis et regule sancti Basilii [...]'; Jan Want in 1519: '[...] een cloester van sunte Basilio oorden ende syn Griecken [...]'. Cavaglià and Rossebastiano 1999, 115; Hassler 1843-1849, vol. 1, 164; Sollweck 1892, 80; Beurden 1896, 171.

20 English anonymous (1425), in Purchas 1905, 546-547. In 1495 Count Alexander von Pfalz-Zweibrücken corroborated this: 'Darinnen ist ein hübsches Kloster unseren lieben Frau, genannt Astaranalle, da ist unsere liebe Frau fast gnädig. Darinnen sind Mönche, Griechen, Eremiten oder Einsiedler. Man sagt, in der Insel will unsere liebe Frau nicht leiden kein weibliches Tier. Und liegt hart neben unserer lieben Frau eine andere Insel, da alle weiblichen Tiere innen sind.' Karbach 1997, $5^{6}$.

21 Mousouras 2003, 29; Poulimenos and Stoufi-Poulimenou 1998, 211 and n. 8. 
The monastery of Strophades is today dedicated to the Christ Redeemer

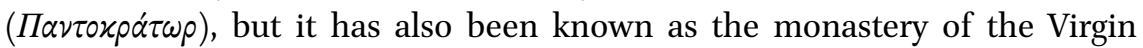

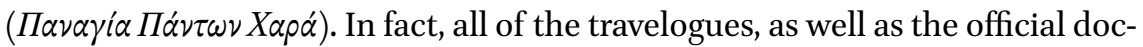
uments of the studied period, refer to it as the 'Virgin of Strophades'. ${ }^{22}$ Whether the latter was the actual dedication of the monastery or an attribution because of the famous miraculous icon of the Virgin Thalassomachousa that was held in it has not yet been determined. ${ }^{23}$

The monastery's present form is the result of years of building activity. ${ }^{24}$ It underwent three main building phases: one up until 1484, one covering the years of the Venetian presence in the area (1484-1797) and one beginning after the end of the Venetian occupation. Its precise date of construction has not been determined with certainty. It is considered to have been built in the late 13th century or the early 14 th. ${ }^{25}$ The building has undergone several minor or major renovations during its history, since it was often damaged either by earthquakes or by enemy raids and pirates attacks. The two major renovations date to 1440 and 1609 . The renovation of 1440 is attributed, according to chronicles, to John viI Palaiologos, but neither the attribution to the emperor

22 Mousouras 2003, 29; Tsougarakis and Schabel 2015, 61-62; Merkouri 2020, 25. About the icon of the Virgin Thalassomachousa kept and venerated in the monastery of Strophades, see Konomos 1988, 46; Konomos 1969; Acheimastou-Potamianou 1997, 46-49; Acheimastou-Potamianou 1999; Acheimastou-Potamianou 200o; Baltoyanni 2000.

23 Dionysios Mousouras, who has thoroughly studied the history of the monastery, suggests that its first dedication was to the Virgin, while it was renamed at some point after 1500 when it was joined to the monastery of the Redeemer in Lithakia in Zante. Mousouras 2003, 29 .

24 About the architectural phases of the monastery, see Poulimenos and Stoufi-Poulimenou 1998; Theodoropoulou 2006; Merkouri 2020, 25.

25 Archaeological remains of its earlier phase have been dated to after the 13th century. According to the prevailing tradition, it was built by the emperor of Nicaea, Theodore I Laskaris, and his daughter Irene, whose names were mentioned on the (now lost) diptychs of the monastery. It should also be noted that there are testimonies stating that there was an inscription above the monastery's entrance, no longer extant, mentioning a date of construction earlier than the 13th century, while in 1809 the British consul of the Septinsular Republic, Waller Rodwell Wright, wrote in his poem Horce Ionicce that the monastery was built during the reign of Justinian, thus moving its date of construction back to the 6th century. Miller 1908, 534; Poulimenos and Stoufi-Poulimenou 1998,

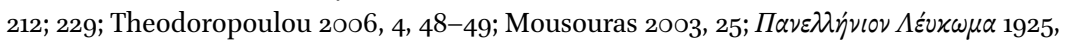
235. About the diptychs, see Zois 1955, 317, 418; Chiotis 1858, 535-536; Merkouri 2020, 25. More recently, it has been suggested that the monastery was founded after the reconquest of Constantinople in 1261 by followers of Patriarch Arsenios Autorianos. See Tsougarakis 2015, 62, esp. n. 5 . 
nor the exact date of the renovation can be supported sufficiently by other sources. ${ }^{26}$ During the period between 1643 and 165 o large-scale construction works were also carried out at the monastery compound, and it is then that the body of the island's saint, St Dionysius, was moved from his tomb to the narthex of the katholikon. ${ }^{27}$

As far as the building complex of the monastery is concerned, during the period of this study it was actually a strong four-storey fortified tower (Fig. 42). The katholikon was located inside the tower, while there was no separate building for housing the monks, who seem to have resided in the same building, on the storeys above the church. ${ }^{28}$

During the period of the Venetian presence in the area, the katholikon, as well as the tower housing it, were enlarged. However, throughout the time frame of this study and before the 17th-century restoration, the monastery's katholikon continued to be the small church of the first phase of the building. In its present form, which retains the main characteristics of the renovation of 1609 and its extension to the east, the katholikon is divided into two parts, the narthex to the west, occupying the space of the church of the first phase of the monument, and the main church, which is accessed by three arched doors with a decorative frame, to the east (Fig. 43). ${ }^{29}$ The floor of the narthex is covered with stone tiles, while it bears in the centre an omphalion adorned

26 The tradition about the renovation of 1440 by the Emperor John viI Palaiologos is mentioned in a chronicle that was published in 1854 by Nikolaos Katramis. The date, as well as the attribution of the renovation to John vir Palaiologos is not accepted by all scholars. Dionysios Mousouras, for example, maintains that the renovation most probably happened in 1428-1430, while Anna Lambropoulou suggests that the date 1440 survived in the chronicle simply because it was the date when the imperial delegation was sailing back from the Council of Ferrara-Florence. Katramis 1854, 32-33; Mousouras 2003, 56-63; Lambropoulou 1994, 296; Merkouri 2020, 26.

27 According to archival evidence, in 1643, within the framework of the building activity

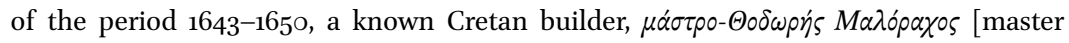
Thodoris Malorachos], was called to the monastery. As recorded in the same archives, repairs were made to the katholikon during the same period. Sathas 1869, 123; Poulimenos and Stoufi-Poulimenou 1998, 213. St Dionysius, who was a monk at the monastery of Strophades and later an archbishop of Aegina, was buried, at his request, on the island in 1622 . His relic was soon related to miraculous interventions, and he was later canonised. In 1717 the saint's body was moved for protection to Zante, and he soon became the patron saint of the island. The life, canonisation and increasing popularity of the saint are not discussed in the chapter concerning the Strophades, since they fall beyond the time frame of this study, that is, well into the 17 th century. About the life of St Dionysius, see indicatively Konomos 1969 .

28 Poulimenos and Stoufi-Poulimenou 1998, 229.

29 Poulimenos and Stoufi-Poulimenou 1998, 228; Theodoropoulou 2006, 34-36; Mousouras 2003, 75 . 

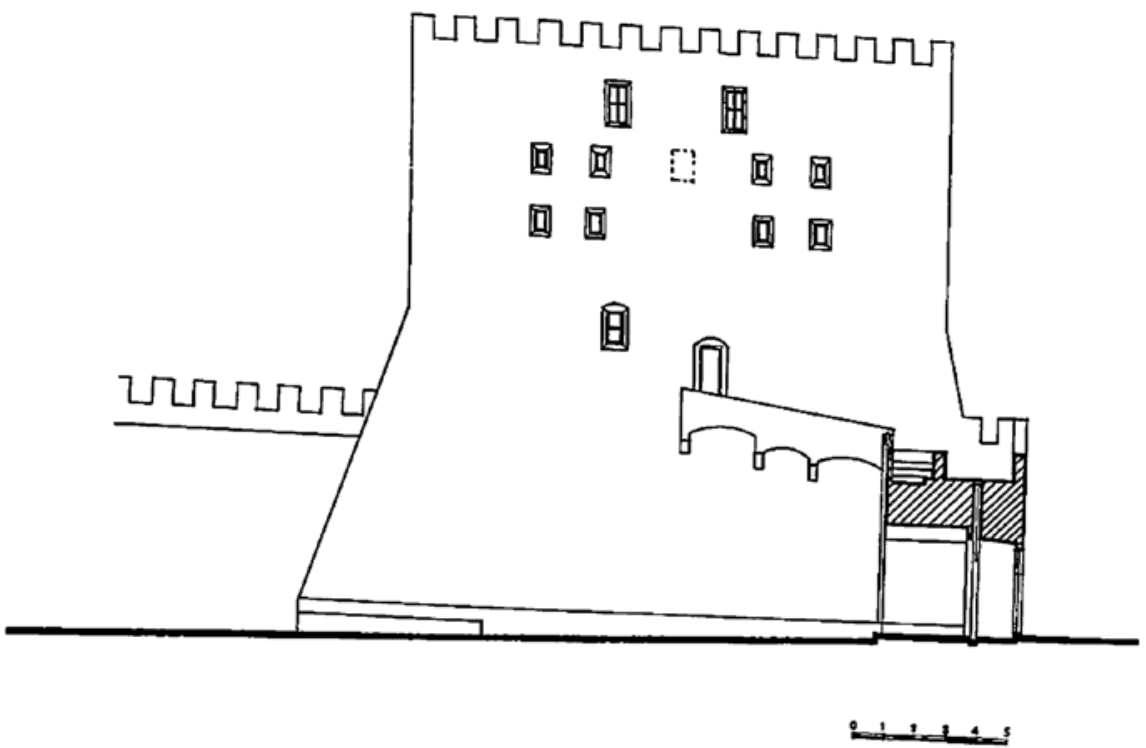

FIGURE 42 The monastery of Strophades during its first building phase (up to 1484)

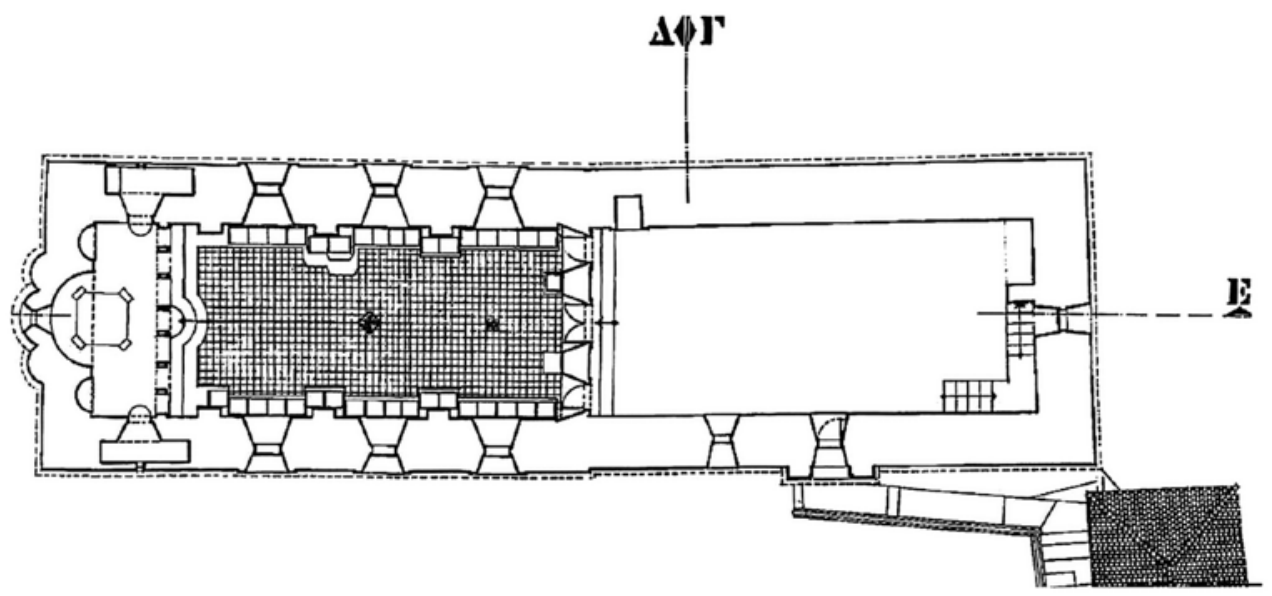

FIGURE 43 Plan of the katholikon of the monastery of Strophades, after the 16og renovation

with the double-headed eagle. At the west end of the narthex, there are ladders leading to the upper floor, while on its south wall there is a niche decorated with a frame, where the body of St Dionysius was kept up until $1717 .{ }^{30}$ The main church is of the common Heptanesian type: a single-aisled large rectangular

$30 \quad$ Poulimenos and Stoufi-Poulimenou 1998, 218; Theodoropoulou 2006, 48. 
space elevated by three steps on its east side, forming the level for the sanctuary. There are three large arched windows on the side walls. The floor is covered with glazed tiles bearing two omphalia with the double-headed eagle, one in the middle of the church, a common Heptanesian feature, and one in front of the central door. ${ }^{31}$ The roof is wooden and without decorative elements. The iconostasis is made of stone. It has pillars without capitals, decorated with series of beads and reels, while decorative borders frame the icons of the Dodekaorton. The apse of the sanctuary is shallow, and at its north and south sides there are two small vaulted rooms, today used as sacristies. The altar, located in the middle of the central apse, is covered by a wooden ciborium. ${ }^{32}$

As already mentioned, up until the end of its Venetian period the monastery did not have separate buildings for housing the monks. The two two-storey wings that exist to this day, housing the monks' cells, the refectory, mills and the church of St George, all date to after the Venetian period of the monument. ${ }^{33}$

The exterior of the tower bears rich morphoplastic elements of different periods, while the sanctuary of the katholikon is distinguished by a composition of three small apses with decorative features (Fig. 44). ${ }^{34}$ The compound of the monastery was also enlarged during the Venetian period and it has been reinforced several times, along with the tower. Built following all the rules of fortification, the monastery was carefully designed in order to be impregnable, as it proved to be. Located in a strategic spot on the sea route from the West to the East and having wells of valuable fresh water, it was used both by the Byzantines and the Venetians, as well as by all the other political powers that dominated the area throughout its history, as a safe harbour and an observation post for the fleets sailing the Ionian. ${ }^{35}$ Additionally, it was conceived to be a stronghold of Christianity and, for the Greeks, a bastion of Orthodoxy.

As can be deduced from written sources of the period, the monks residing at the monastery were, at least from the beginning of the $15^{\text {th }}$ century, Greek

31 Theodoropoulou 2006, 36; Poulimenos and Stoufi-Poulimenou 1998, 219.

32 Poulimenos and Stoufi-Poulimenou 1998, 219; Theodoropoulou 2006, 34-36.

33 Poulimenos and Stoufi-Poulimenou 1998, 220; Theodoropoulou 20o6, 31-33.

34 Poulimenos and Stoufi-Poulimenou 1998, 220; Theodoropoulou 2006, 31-33.

35 There are several indications in archival documents concerning important information in relation to ships sailing near the islands, provided by the monastery's monks to the Venetian authorities. In July 1520 the Proveditor of Zante, Sebastian Contarini, was informed that the pirate ships that had looted Reggio Calabria were seen travelling to the East. In December of the same year Contarini sent two men to the monastery as lookouts, in order to inform the Venetians located at Modon (which was at the time under Ottoman occupation) about the whereabouts of the Ottoman fleet. In 1531 the monks informed the authorities of Zante that three ships of the Hospitaller Knights docked at the island's port. See Sanuto 1899, cols 58, 464, 56o; Kolyvà 2015, 182. 


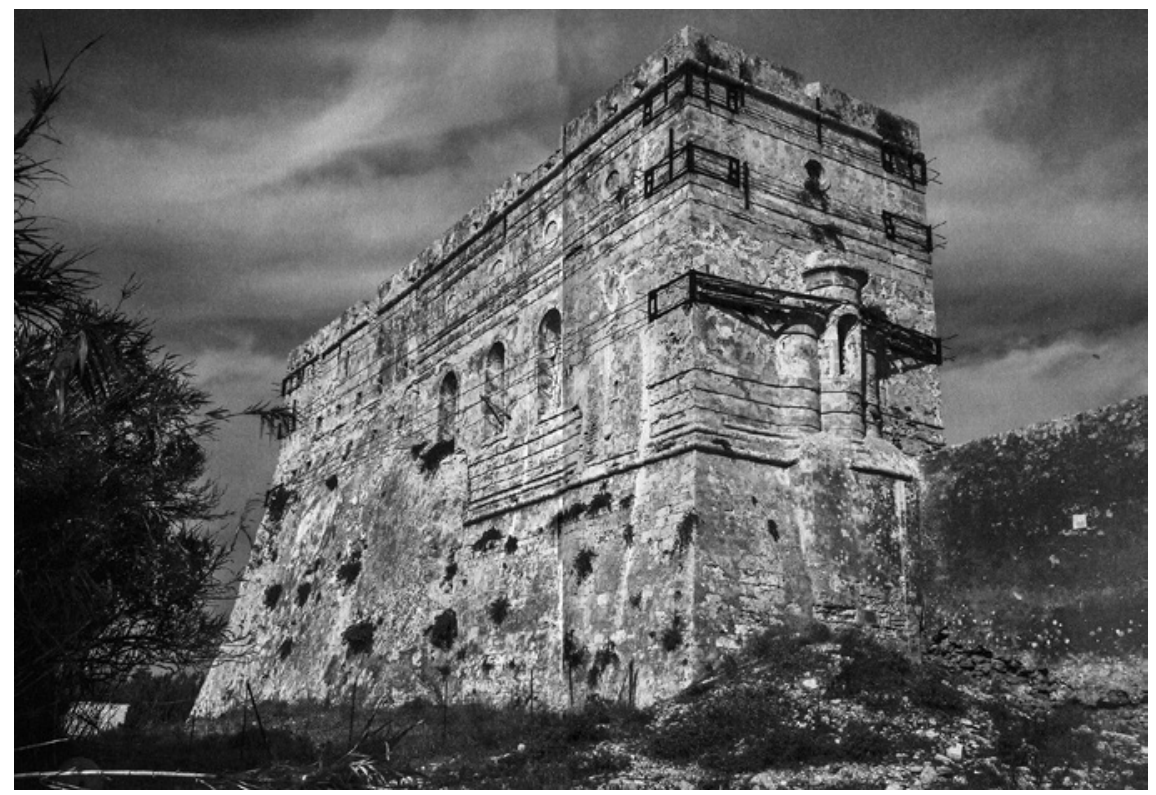

FIGURE 44 The east side of the tower and the apses of the katholikon of the monastery of Strophades

Orthodox..$^{36}$ Their strict way of everyday life and mainly their composite identity as warrior-monks seem to have really impressed the pilgrims, who, as mentioned above, convey relative information in most of their narratives when referring to Strophades. The number of monks living at the monastery varied, but, in broad lines, was significant. In 1420 Cristoforo Buondelmonti mentioned

36 The ecclesiastical status quo of the monastery during the 13th century remains obscure. If one accepts the well-rooted tradition that attaches its construction to the imperial Laskaris family, the obvious assumption would be that the monastic brotherhood that originally manned it was Greek Orthodox. However, it has been suggested in the absence of other concrete evidence that the monastery was founded not as a Greek house, but as a Latin one. Two papal letters dated 1299 and 1306 clearly attest to a Latin presence at the monastery. In fact, in the second letter the monastery is referred to as b. Mariae de Strofaria ord. S. Ben Cephaluden. Nonetheless, if the monks residing in the monastery were actually Benedictines, and what the exact period of their presence there was, is not known. William Miller suggested that the Benedictines governed or controlled the monastery in the 13th century, but, when the Greeks recovered Achaia, the Emperor John vi restored it. While this question remains to be answered, what can be safely deduced is that at least from the early $15^{\text {th }}$ century, as attested by many travelogues, as well as other documents, the monastery was manned by Greek Orthodox monks. Mousouras 2003, 25-29, 38-43, 48-51; Tsougarakis 2012, 86-87; Bon 1969, 93; Fedalto 1978, 238; Digard et al. 1935, 540-541; Registrum Clementis 1892, 283-284; Miller 19o8, 534; Tsougarakis 2015, 61-66 and passim. 
that more than 50 monks were living at the monastery at the time of his visit, while in 1482, according to the Franciscan friar Paul Walther Guglingen, '200 Greek priests and 300 lay brothers' resided there. ${ }^{37}$ The French Benedictine monk Nicolas Loupvent (1531) states that, "The island is inhabited only by the monks residing at the monastery of the Virgin, who are Orthodox, officiating in the Greek language and following the Orthodox rite, and they are always, if this is possible, around $5^{\mathrm{O}}$ in number.'38 Narrations of the $17^{\text {th }}$ and 18th centuries corroborate Loupvent's assertion about the number of the cenobites: George Wheler, a 17th-century English clergyman and travel writer, attests that in 1686 the monks of the Strophades monastery were around 50 or $60 .{ }^{39} \mathrm{At}$ the end of the 18th century, according to André Grasset de Saint-Sauveur, the French state functionary who lived on Corfu for several years (1781-1798), there were around 40 monks residing on the island..$^{40}$ Other pilgrims mentioning the monastery may not be as specific, but they state that 'numerous Greek monks' lived on the island. ${ }^{41}$

As discussed above, the monastery often suffered pirate or enemy raids. It was severely damaged at least three times by the Ottoman fleet, in 1479, in 1530 or 1537 and in 1571, while it was almost destroyed in 1717 by the Ottoman pirate Moustis, who plundered the tower, captured 24 monks and looted almost all of its valuable possessions, among which were the arms of the highly venerated relic of St Dionysius and the miraculous icon of the Virgin Thalassomachousa. ${ }^{42}$ Despite all these events, the monastery of Strophades, usually with the valuable financial aid of Venice for the liberation of captured monks, as well as for repairing the damaged buildings, survived and prospered and has been an important monastic, spiritual and cultural centre of Orthodoxy. It was active during the 18 th and 19th centuries, while in recent years only one monk resided there; after his death in July 2017, the monastery's long history seems to have

37 Cristoforo Buondelmonti (1420) '[...] et ex omni progenie plus quam quinquaginta ibi coadunati reciantur'. Bayer 2007, 13. Paul Walther Guglingen (1481-1483): 'Et in illa est monasterium nomine Kalorea, in quo sunt continue ducenti presbyteri greci et trecenti fratres laici, omnes ordinis et regule sancti Basilii et dicuntur Kalorier de Striffali.' Sollweck 1892, 79 .

38 See $n .16$ above.

39 ' [...] il y a un Convent de cinquante ou soixante Grecs, qui defend de la peur des Corsaire leurs Nôtredame miraculeuse, par le moyen de quelques Bastions garnis de bons Canons'. Wheler 1689, 7 o.

40 'La communauté forme seule toute la population. Elle est composée de plus de quarante religieux, dont sept à huit prêtres.' Grasset de Saint-Sauveur 180o, 321.

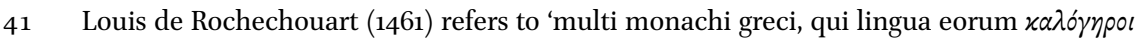
nuncupantur'. Couderc 1893, 232.

Poulimenos and Stoufi-Poulimenou 1998, 214; Mousouras 2003, 77-87. 
reached its end. An earthquake on 26 October 2018 sealed the monastery's fate, causing severe damage to most of its buildings.

\subsection{The Icon of the Virgin Thalassomachousa}

One of the most valuable and venerated possessions of the Strophades monastery was the miraculous icon of the Virgin, known as 'Thalassomachousa' (Fig. 45)..$^{43}$ The epithet Thalassomachousa, meaning the sea fighter, probably derived from the tradition according to which the icon arrived at Strophades, travelling by sea from Constantinople during iconoclasm, a common topos concerning the finding of miraculous icons. ${ }^{44}$

The icon of the Virgin Thalassomachousa, most probably a despotic icon in its original use, is the oldest icon of the monastery to survive to this day. It was located in the narthex of the katholikon, but, following the earthquake of 1997, which damaged the monastery's buildings, it was moved to the monastery of Strophades and St Dionysius in Zakynthos. The icon, dated to the beginning of the 13th century, is considered to be the work of a Constantinopolitan artist, an attribution that could be used as an additional argument to underline the relation of the monastery to the imperial family of Laskaris. ${ }^{45}$

In its present form, and after the removal of the Post-Byzantine overpainting, only the central figures of the Virgin holding the Christ Child, painted on a gold background, have survived from the original 13 th-century icon. ${ }^{46}$ The depiction is a rare variation of the Glykofilousa type. ${ }^{47}$ The Virgin is holding the Christ Child with both hands, while he administers a blessing with his right hand and holds a scroll in his left. The rare variation of the Strophades Glykofilousa icon is iconographically related to an icon of the 12th or 13th century kept at the Kremlin in Moscow. ${ }^{48}$ The gesture of Christ administering a blessing, unusual for the Glykofilousa type, can also be seen in an icon of the Virgin Dexiokratousa in Moscow, dated to the late 14th century

43 About the icon of the Virgin Thalassomachousa, kept and venerated in the monastery of Strophades, see Konomos 1988, 46; Konomos 1969; Acheimastou-Potamianou 1997, 46-49; Acheimastou-Potamianou 1999; Acheimastou-Potamianou 2000; Baltoyanni 2000. Acheimastou-Potamianou 1997, 46; Acheimastou-Potamianou 2000, 472.

45 Acheimastou-Potamianou 1997, 48; Acheimastou-Potamianou 200o, 472.

46 The icon had several layers of overpainting that were removed in order to reveal the original depiction. Cod. 14 of the monastery refers to an avaxaivio [restoration] of the icon in 1836 by the deacon and painter Laurentios. Koutelakis 1994, 67-68; Lykogiannis 2003, 585 ; Acheimastou-Potamianou 1997, 48; Acheimastou-Potamianou 2000, 472.

47 Baltoyanni 1994, 155-156.

48 Acheimastou-Potamianou 1997, 48; Acheimastou-Potamianou 2000, 472; Lutsko 1992, 539, pl. 297 . 


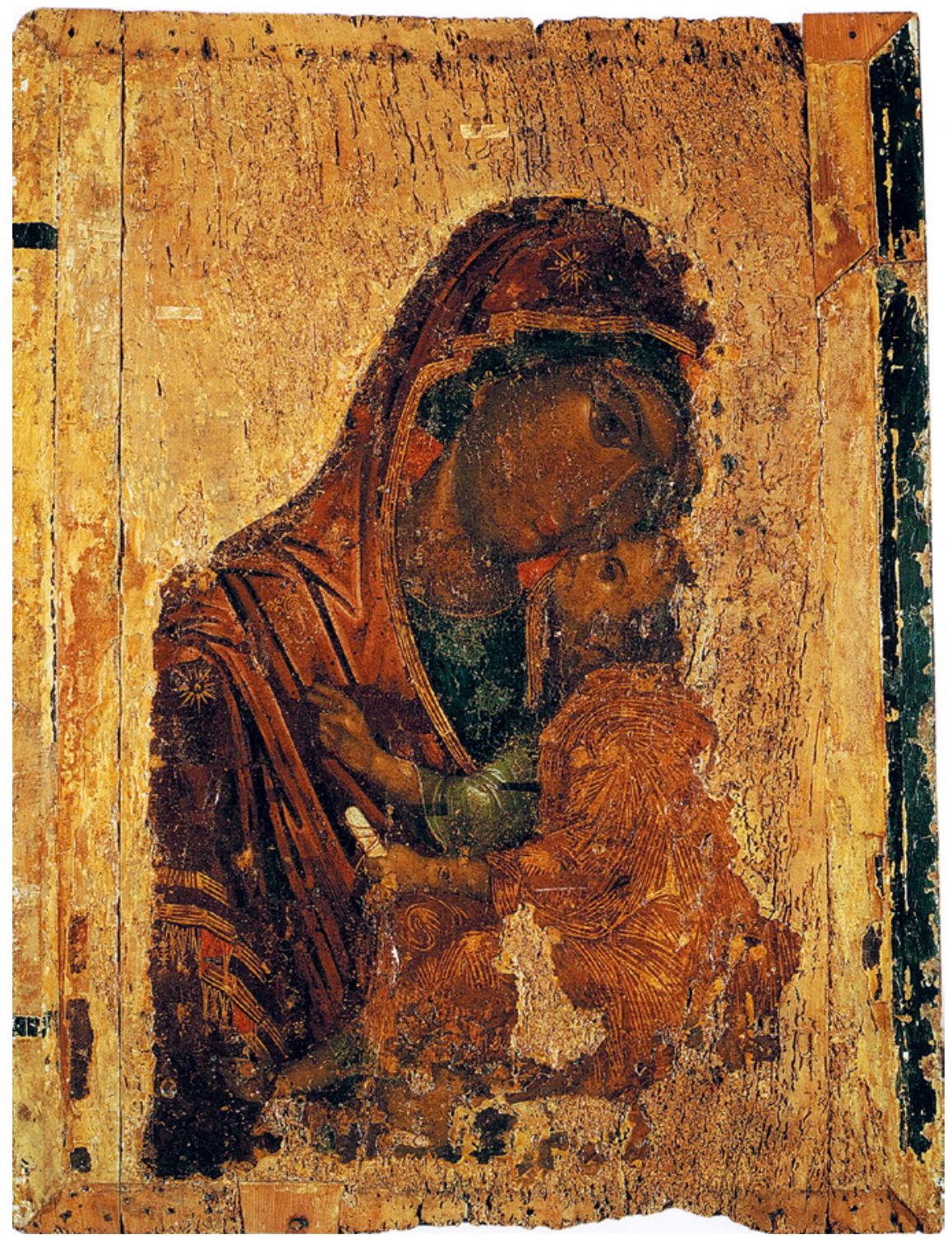

FIGURE 45 The icon of the Virgin Thalassomachousa

and attributed to the famous Constantinopolitan painter Theophanis 'the Greek', as well as in a number of Cretan icons of the $15^{\text {th }}$ and 16th centuries. ${ }^{49}$ As already mentioned, the iconographical elements of the icon provide clear

49 Acheimastou-Potamianou 1997, 48; Acheimastou-Potamianou 20oo, 472; Baltoyanni 1994, no. 48 . 
indications for its dating to the early 13th century and its attribution to a Constantinopolitan workshop. ${ }^{50}$

On 19 August 1717 the Strophades monastery's most venerated icon was stolen along with other precious possessions, including the arms of St Dionysius, during a pirate raid..$^{51} \mathrm{~A}$ narration of the raid has survived in a chronicle published by Nikolaos Katramis in 1854, while, according to another manuscript of the same chronicle that provides a more detailed version of the narration, the miraculous icon was sold by the pirates on the island of Patmos to an archpriest called Agathangelos. ${ }^{52}$ The icon's presence on the island of the Apocalypse for a substantial amount of time may also be attested by a fresco in the church of St Basil, which is dated to 1722 and copies the Strophades Thalassomachousa; the icon of the Virgin is believed to have been returned to the Strophades monastery in the same year. ${ }^{53}$

Just like the icon of the Virgin Kassopitra, the Strophades Thalassomachousa was also said to have had a perpetual lamp burning before it. The oil of this lamp was dripped in the sea before embarking on a journey in order to ask for calm waters. ${ }^{54}$ It was a highly venerated icon, known not only to the local inhabitants of the neighbouring islands, but to the mariners as well, since it was evoked in the Santa Parola. ${ }^{55}$ The fame of the icon is what makes even more peculiar the fact that, unlike the monastery, it is not, at least directly, referred to in the pilgrims' travelogues. ${ }^{56}$

$5^{\circ} \quad$ Acheimastou-Potamianou 1997, 46; Acheimastou-Potamianou 2000, 472.

$5^{1} \quad$ Mousouras 2003, 78-81; Konomos 1969, 64-66.

52 According to Dionysios Mousouras, the archpriest mentioned in the chronicle became a monk at the monastery of St John the Theologian on Patmos in 1722 and he took with him, as mentioned in the monastery's archives, several relics, vestments and a Russian icon of the Virgin. This reference, when combined with his will, in which he bequeathed the Thalassomachousa icon to the consul of Zante, led Mousouras to the conclusion that Agathangelos was not the one who bought the Strophades Virgin. Regarding the Thalassomachousa icon, he conveys information from a Synaxarion, as well as the manuscripts of the monastery of St John, according to which it was bought by two Patmian brothers, Elias and Theodoros Kokkinakis. Dinos Konomos agrees that it was the two brothers who bought the icon. Katramis 1854, 32-33; Mousouras 2003, 78-81, 85, n. 199; Konomos 1969, 66 .

53 The fresco is a work of the painter Stavrianos Chios and bears the inscription $H$ АГІА $E I K \Omega N$ THEC MONHC TSN CTPOФA $\triangle \Omega N$ [the holy icon of the monastery of Strophades]. Koutelakis 1994, 67-68.

54 Acheimastou-Potamianou 1997, 46; Acheimastou-Potamianou 2000, 472.

55 'Die n'ai'e Santa Maria de le Scanfarie'. Bacci 2004b, 244.

$5^{6}$ As already mentioned in regard to the icon and the church of the Virgin in Kassiopi, it was not an uncommon phenomenon for seafarers and travellers to evoke a site instead of a specific icon, relic or saint. See pp. 27-28 herein. 
The monastery of Strophades, despite its geographical isolation and small size, is mentioned almost as many times as the cathedrals of Modon and Candia and more than all the religious institutions of Corfu combined. Given that the pilgrims convey so much information about the monastery and the monks residing in it, it would be quite improbable that they were unaware of the icon's existence. If anything, the crew of their galleys would have informed them about it, as in many other instances. Taking into consideration the confined space within the tower that also served as the katholikon and the very small port of the island, one could assume that most of the travellers did not actually disembark and visit the monastery, but rather saw it from aboard. This could explain to a certain extent the absence of mentions to the icon. On the other hand, it is not uncommon for pilgrims to refer to and even provide descriptions of icons, churches or relics they did not actually see. A similar phenomenon can be seen in the case of the Virgin of Kassiopi: while the church and all the legends concerning it are mentioned by a large number of pilgrims, only a few of them refer to its highly revered miraculous Lucan icon of the Virgin Kassopitra.

However, and although none of the travelogues specifically refers to the icon, hints of its existence can be traced in several of them. For example, when pilgrims refer to 'our beautiful gracious Lady', one could plausibly assume that they were referring to the Thalassomachousa icon. ${ }^{57}$ The Czech scholar Oldřich Prefát, who travelled to the Holy Land in 1546 , mentions the monastery of the Virgin, stating that great miracles had happened there, while he adds that members of the crew salute the Virgin by singing Salve Regina, while the pilgrims join them. ${ }^{58}$ Whether the Czech pilgrim is referring to the church or the icon, his testimony is of significant importance, since it attests that the mariners treated Strophades as a Marian cult site. ${ }^{59} \mathrm{~A}$ century later, in 1686, the English clergyman George Wheler obviously refers to the icon when mentioning the monks who 'defend their miraculous Virgin' using arms and cannon. ${ }^{60}$

57 Count Alexander von Pfalz-Zweibrücken (1495-1496), see n. 20 above.

58 'v tom pak jednom větším jest klášter a kostel Panny Marye, která slove vlasky Santa Maria de Striauli, a pravil, že by veliké divy se tu stávaly. Protož skalko (to jest náš kuchmistr) uhlédav ty ostrovy, pozdravuje tu Pannu Maryji začal zpívati Salve Regina a my s ním zpívali.' Bočková $2007,72$.

59 About the Marian cult sites on the same route, see p. 11, n. 5 herein.

6o See n. 39 above. 
The monastery of the Virgin of Strophades was a significant stopping point and pilgrimage site on the way from Venice to the Holy Land. Located in open sea, the small port provided protection for the ships passing by, as well as springs of clean water, while the monastery offered the notion of divine protection for a safe journey. The uniqueness of the fortified building housing the monastery and the imposing and evocative landscape rendered it an ideal pilgrimage site. The small islands and the strongly fortified tower-monastery seem to have really intrigued the pilgrims, providing an imposing topographical and architectural framing to the sacred icon. The islands, a liminal place between sea and land, heaven and earth, were also visually extremely emotive. To the above one should add the presence of the monastery's monks who, being Greek Orthodox and thus somehow 'exotic' to the eyes of Westerners, seemed to exert a great impact on the pilgrims, which is aesthetic and visual as well. This impression was enhanced by the particularly strict way of life of the Strophades cenobites, as well as their resistance to the Ottomans, which undeniably augmented the prestige of their sacred habit among the pious travellers. ${ }^{61}$ The monastery has been throughout its history supported, mostly financially, by the prevailing political actors of the area and mainly the Venetians, who for a time became its overlords. However, this was a clear political act, aimed at the use of the island's port, and does not seem to have had anything to do with the cult of the Virgin Thalassomachousa. There does not appear to have been an organised promotion of the cult or of the site as a pilgrims' destination by any political or religious actor. So, while it was the pilgrims who inserted it in their sacred topography and made it known to a wider audience, the role of the seafarers in the promotion of the site was undeniably critical. In the end, just as in the case of the Virgin of Kassiopi, the Strophades monastery's inclusion in the sacred topography of the sea route to Jerusalem is inextricably linked to the circumstances of navigation as perceived and experienced by the mariners, who had already included it in their 'holy topography of sailing', and the pilgrims, who elevated it to an international level.

61 Miller 19o8, 534-535. 